\title{
Occurrence of Sulphate Reducing Bacteria (SRB) Associated with Biocorrosion on Metallic Surfaces in a Hydroelectric Power Station in Ibirama (SC) - Brazil
}

\author{
Paulo Roberto Dantas Marangoni ${ }^{1 *}$, Diogo Robl ${ }^{2}$, Marcos Antonio Coelho Berton ${ }^{1}$, Carlos \\ Mario Garcia ${ }^{3}$, Angela Bozza ${ }^{2}$, Mariana Vieira Porsani ${ }^{2}$, Patricia do Rocio Dalzoto ${ }^{2}$, Vânia \\ Aparecida Vicente $^{2}$ and Ida Chapaval Pimentel ${ }^{2}$ \\ ${ }^{1}$ Instituto Senai de Inovação em Eletroquímica; Serviço Nacional de Aprendizagem Industrial; Curitiba - PR - Brasil. \\ ${ }^{2}$ Departamento de Patologia Básica; Universidade Federal do Paraná; Curitiba - PR - Brasil. ${ }^{3}$ Departamento \\ SOM/DEMG/VEMU; Companhia Paranaense de Energia; Curitiba - PR - Brasil
}

\begin{abstract}
The aim of this study was evaluate, two methods for the detection and identification of sulphate reducing bacteria (SRB): ML medium and PCR with specific primers for SRB groups. SRB were detected through the selective medium only on carbon steel, which showed corrosion. Employing specific PCR primer, SBR were detected from all the metallic components assayed, even those that did not present visible corrosion spots, such stainless steel and copper alloys. Despite the presence or absence of corrosion at the later stages effectively by using the selective medium,, the initial stages of the corrosion could only be detected by the amplification of total DNA with SRB specific primers. The early detection of SRB could be employed for preventing the damages on metal surfaces before the installation of corrosion processes. Strategies for reducing the time spent on SRB isolation and identification could be auxiliary tools for controlling the corrosion of materials.
\end{abstract}

Key words: Metallic surface, hydroelectric power station, biofilm, biocorrosion

\section{INTRODUCTION}

Biocorrosion, or Microorganism Influenced Corrosion (MIC), is a serious degradation process being faced by the energy production and industrial sectors, mainly in the tropical, or subtropical climate countries. The microorganisms are arranged in a biofilm formed by the extracellular polymeric material (EPM) produced by them (Kumar et al. 2011). The production of organic deposits on the surface of equipment at, for example, hydroelectric power stations is often known as "biofouling". It can be present in stationary and fast flowing, or turbulent water.
Usually, these deposits lead to a significant reduction in the efficiency and useable lifetime of the equipment. Many studies have been carried out on the MIC, but only few have focused on the process as it occurs in the contaminated water, or in the river (non-saline) water (Heitz et al. 1996; Beech and Gaylarde 1999; Videla 2003; Schaechter 2004; Romeo 2008; Simões et al. 2010).

Frequently, immersed metals suffer biological degradation (biocorrosion) as well as physical and chemical processes that lead to corrosion. Physical and chemical degradation can cause intense changes in the behavior of the metal/solution

*Author for correspondence: paulo.marangoni@pr.senai.br 
interface. All these processes occur at the same time and, as result, a new metal/solution interface is generated, which can accelerate the MIC. The corrosion and weathering caused by the biofilms can lead to reduced efficacy of heat exchangers, unexpected corrosion of stainless steel and premature destruction of mineral materials (Marshall et al. 1994).

Although there have been several studies about MIC over the last few years, biocorrosion processes are still poorly understood. Economic losses due to equipment damage by the biocorrosion are combined with those resulting from biofouling. Despite large economic losses, such processes are not totally accounted for Brazil, where $70.3 \%$ of energy production originates from hydroelectric power stations (ANEEL 2012). These stations can be seriously affected by biofouling and biocorrosion, especially given Brazil's suitable climatic conditions for biofilm development in natural waters (Beech and Sunner 2004). Thus, for a better understanding of the MIC processes, it is essential to isolate and identify the microorganisms associated with the biocorrosion of immersed metals. An understanding of the relevant microorganisms in the biofilms and their metabolites could lead to strategies for reducing the financial losses and minimizing the effects of MIC (Eguía et al. 2007).

Sulphate-reducing bacteria (SRB) are the major group of microorganisms linked to anaerobic corrosion (Beech and Sunner 2004; Zadvorny et al. 2006). The diversity of microorganisms from the environmental samples has been commonly assessed by phenotypic and genotypic characterization of cultivable organisms. However, this represents only a small portion of the actual biodiversity in those environments. The identification of anaerobic bacteria such as Desulfovibrio sp by microbiological tests is often difficult and time consuming (Marschall et al. 1993). The acidophilus microorganisms, which accelerate the oxidation of iron surfaces (Videla 2003), show great diversity, but their isolation and identification, are also restricted due to technical limitations. In an attempt to minimize these difficulties, metagenomics have emerged as a strategy to quickly and efficiently access the microbial diversity in environmental samples.
Purified DNA is representative of all the microorganisms present in a sample; amplification with specific primers for particular DNA sequences allows only the target organisms to be identified among the others (Ben-Dov et al. 2007; Boden et al. 2012).

The use of these methods allows direct access to information about the structure of biofilms communities. Genes encoding ribosomal RNA, as 16S rRNA, were used for designing primers that allow the detection of SRB groups by genus identification (Devereux et al. 1992). Devereux et al. (1996) described the presence of these bacteria in several environments, including anaerobic biofilms. The phylogenetic analysis by means of comparisons among the sequences of $16 \mathrm{~S}$ rRNA allows to classify the genera into distinct groups of SRB (Devereux et al. 1989).

This study aimed to detect and identify the SRB from metallic surfaces showing corrosion, with or without visible spot of corrosion in a hydroelectric power station in Brazil by the microbiological tests and through DNA amplification with specific primers for the identification of SRB groups.

\section{MATERIAL AND METHODS}

\section{Sampling and data collection}

The experiments were conducted during the construction of a hydroelectric power plant in Ibirama-SC, Brazil (Salto Pilão hydroelectric power station in the Itajaí-Açú River, Figure 1. In order to investigate the MIC, seven samples of metal alloys were used (Table 1). Twenty-eight metallic coupons (measuring $100 \times 18 \times 2 \mathrm{~mm}$ ) were produced for each metal alloys analyzed. The sets of metallic coupons (MCs) were placed in transparent acrylic boxes at four collection points, two at upstream points of the hydroelectric power plant (surface and deep water) (Fig. 1 A, A1 and A2) and two at downstream points of the powerhouse in the hydroelectric power plant (surface and deep water) (Fig. 1 B, B1 and B2), with continuous circulating water from the ItajaíAçú River. Samples were collected randomly at two periods: April/2007 and June/2007, totaling seven specimens analyzed for each metal assessed, totaling 49 samples (Table 1 and Fig. 2). 

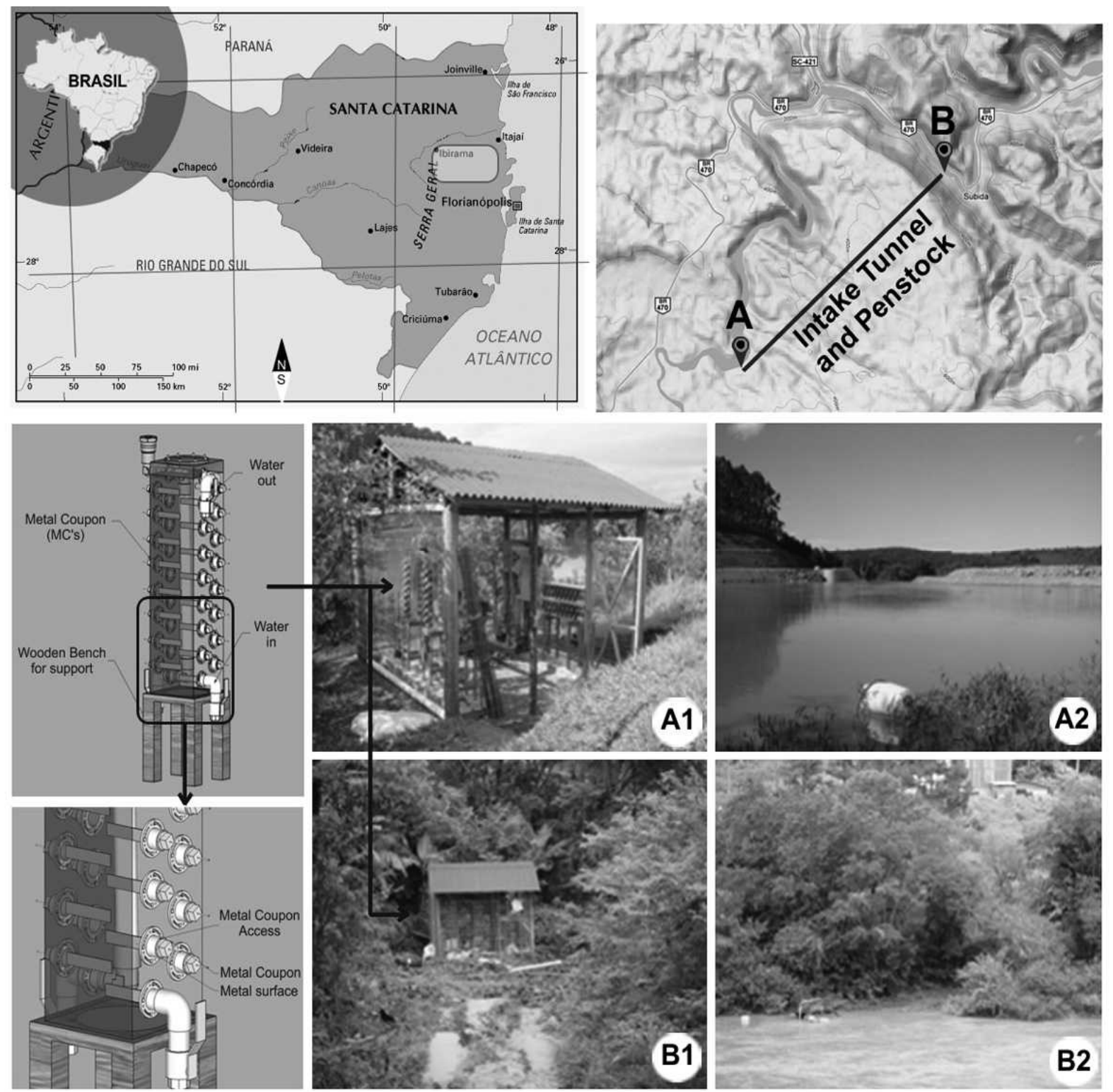

Figure 1 - Geographical location of the hydroelectric power station Salto Pilão on Ibirama (SC) Brazil (2007) and collection points with Acrylic boxes for metal coupons exposure to the influence of the Itajaí-Açú River. Collection point upstream of the power plant (A) and collection point downstream of the power plant (B). Acrylic boxes used for exposure and collection samples.

Table 1 - Metal samples exposed for microbiological detection, specifically SRB in the Itajaí-Açú River, Salto Pilão hydroelectric power station - Ibirama (SC) - Brazil (2007).

\begin{tabular}{lll}
\hline Specification & Type of metal & Equipment \\
\hline ASTM A53 & Carbon Steel & Tubing \\
ASTM A36 & Carbon Steel (average resistance) & Parts fixed (without paint) \\
SAR 50BN & Carbon Steel & Conduct forced \\
ASTM A743 & Stainless Steel (low resistance) & Rotor \\
AISI 410T & Stainless Steel & Wheel, axle \\
INOX AISI304 & Stainless Steel & Support of the fence Gates, railing from the wall of water \\
Cu/Ni 90/10 & Cooper Alloy & drainage, screws \\
\hline
\end{tabular}




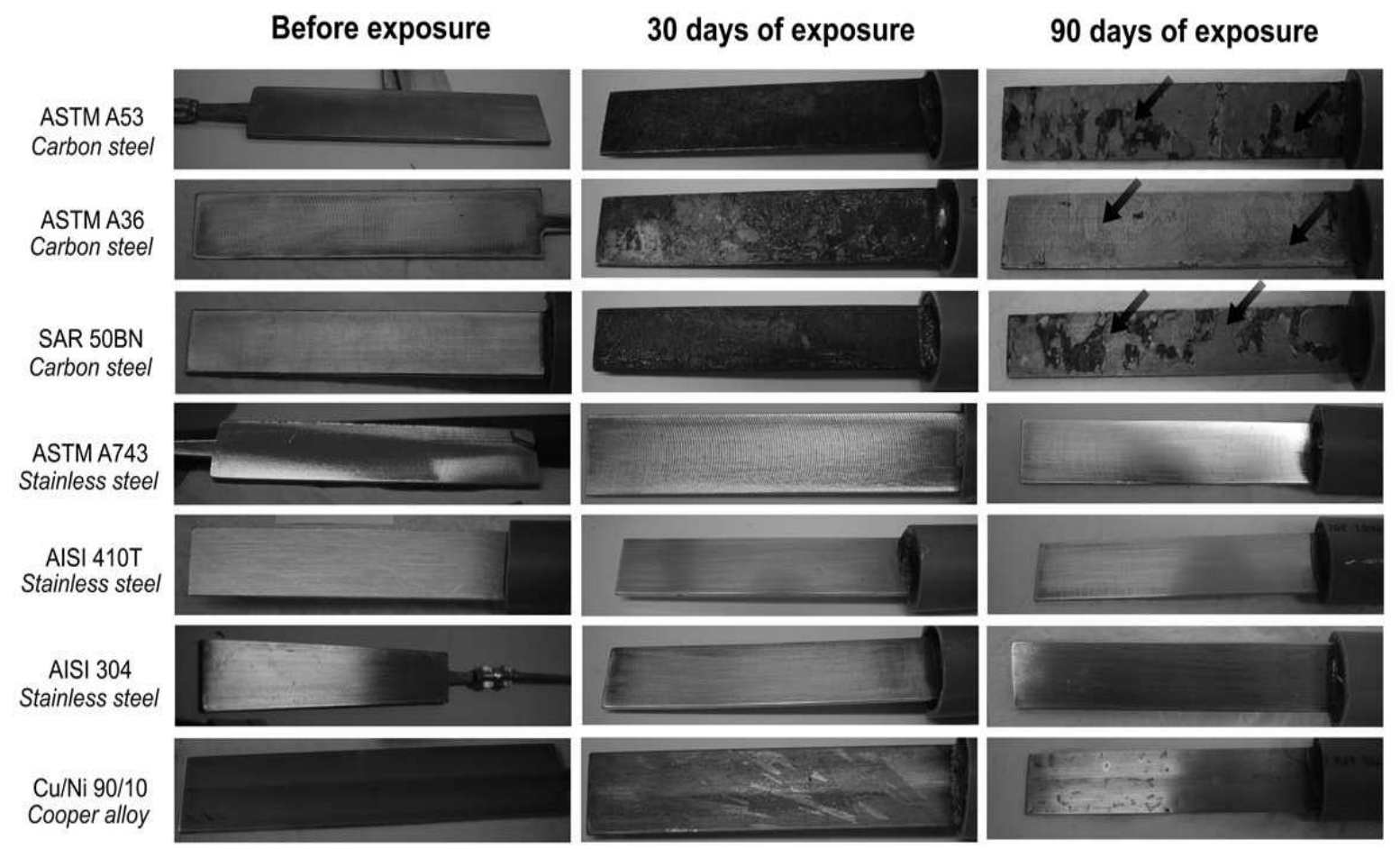

Figure 2 - Samples of seven types of metallic coupons (MC's) placed in the corrosion station in Salto Pilão hydroelectric power station on Ibirama (SC) - Brazil (2007) and collected with 30 and 90 days of exposure.

Detection of Sulphate-reducing bacteria (SRB)

A system was assembled to ensure anaerobic conditions: ML medium was composed of the following $(\mathrm{g} / \mathrm{L})$ : yeast extract 1 , ascorbic acid 0.1 , $\mathrm{MgSO}_{4} 0.2, \mathrm{KH}_{2} \mathrm{PO}_{4} 0.2, \mathrm{FeSO}_{4}\left(\mathrm{NH}_{4}\right)_{2} \mathrm{SO}_{4} \cdot 6 \mathrm{H}_{2} \mathrm{O}$ $0.1, \mathrm{NaCl} 10$ and sodium lactate $(70 \mathrm{~mL} / \mathrm{L})$. The medium $\mathrm{pH}$ was adjusted $(7.3 \pm 0.1)$ previously and transferred into tubes with rubber lids perforated by metallic needles and autoclaved for $15 \mathrm{~min}$ at $120^{\circ} \mathrm{C}$. The system was depressurized for oxygen removal through the needles, which were rapidly removed after autoclaving. The samples were inoculated using $1.0 \mathrm{~mL}$ of each sample injected into $20 \mathrm{~mL}$ of the ML medium, through the metallic needles (Pérez et al. 2007). After incubating in anaerobic incubator for 20-30 days at $30^{\circ} \mathrm{C}$, positive tubes for SRB showed black iron sulphide deposition (Clescerl et al. 1999).

\section{Nucleic Acid Extraction and Determination of DNA Concentrations}

The total genomic DNA was extracted from the tuber of corrosion and biofilm formed on the surface of metallic samples immersed in the ItajaíAçú River, using the MoBio Power Soil DNA isolation kit (MoBio Laboratories, Inc., Solana Beach, CA). The purified DNA was eluted in 100 $\mathrm{mL}$ of solution C6 (MoBio Laboratories, Inc.) and stored at $-20^{\circ} \mathrm{C}$. Power Soil DNA isolation kit solutions $\mathrm{C} 2$ and $\mathrm{C} 3$ are very efficient in removing contaminating organic and inorganic matter (BenDov et al. 2007). DNA concentrations of the samples were determined by the ND-1000 UVVis Spectrophotometer (NanoDrop Technologies, Inc., Wilmington, DE., USA). Gene copy number was calculated on the basis of the measured DNA concentration $(\mathrm{ng} / \mu \mathrm{L})$.

Polymerase chain reaction (PCR) amplification of rDNA with SRB group-specific primers

The PCR reactions were performed with the samples of DNA extracted from the samples collected from the MCs. Reactions were carried out as follows: $95^{\circ} \mathrm{C}$ for $1 \mathrm{~min}$ (denaturation), annealing for 1 min (Table 2 for temperature) and $72^{\circ} \mathrm{C}$ (extension) for 30 cycles. Each reaction tube $(50 \mu \mathrm{L})$ contained: $10 \mu \mathrm{L}$ of each primer $(4 \mathrm{pmol})$ (Table 2), $4.0 \mu \mathrm{L}$ of dNTP $(2.5 \mathrm{mM}), 15.5 \mu \mathrm{L}$ of distilled $\mathrm{H}_{2} \mathrm{O}, 5.0 \mu \mathrm{L}$ of PCR buffer (10x), $1.5 \mu \mathrm{L}$ of $\mathrm{MgCl}_{2}(50 \mathrm{mM}), 1.0 \mu \mathrm{L}$ of $\mathrm{Taq}$ Polymerase 
"Invitrogen" (5 U/ $\mu \mathrm{L})$ and DNA template (approx. 50-100 ng). PCR products were electrophoresed on $1.6 \%(\mathrm{w} / \mathrm{v})$ agarose gel in $1 \mathrm{x}$ Tris/borate/EDTA
(TBE) and detected through ethidium bromide in UV transiluminator. The primers sequences are described in Table 2.

Table 2 - The 16S rDNA-targeted PCR primer sequences specific for SRB subgroups (Daly et al. 2000) employed in this work for detection of sulphate reducing bacteria (SRB) in metallic surfaces in Salto Pilão hydroelectric power station, Ibirama-SC, Brazil (2007).

\begin{tabular}{|c|c|c|c|c|c|}
\hline $\begin{array}{l}\text { Primer } \\
\text { pair }\end{array}$ & Sequence & $\begin{array}{l}\text { Product size } \\
5^{\prime}-3^{\prime}(\mathbf{b p})^{*}\end{array}$ & $\begin{array}{c}\text { Annealing } \\
\text { temperature }{ }^{\circ} \mathbf{C}\end{array}$ & Specificity & Genera \\
\hline $\begin{array}{l}\text { DFM140 } \\
\text { DFM842 }\end{array}$ & $\begin{array}{l}\text { TAG MCY GGG ATA ACR SYK G } \\
\text { ATA CCC SCW WCW CCT AGC AC }\end{array}$ & 700 & 58 & Group 1 & $\begin{array}{l}\text { Desulfotomaculum } \\
\text { sp }\end{array}$ \\
\hline $\begin{array}{l}\text { DBB } 121 \dagger \\
\text { DBB } 1237\end{array}$ & $\begin{array}{l}\text { CGC GTA GAT AAC CTG TCY TCA TG } \\
\text { GTA GKA CGT GTG TAG CCC TGG TC }\end{array}$ & 1120 & 66 & Group 2 & Desulfobulbus sp \\
\hline $\begin{array}{l}\text { DBM169 } \\
\text { DBM1006 }\end{array}$ & $\begin{array}{l}\text { CTA ATR CCG GAT RAA GTC AG } \\
\text { ATT CTC ARG ATG TCA AGT CTG }\end{array}$ & 840 & 64 & Group 3 & $\begin{array}{l}\text { Desulfobacterium } \\
\text { sp }\end{array}$ \\
\hline $\begin{array}{l}\text { DSB127. } \\
\text { DSB1273 }\end{array}$ & $\begin{array}{l}\text { GAT AAT CTG CCT TCA AGC CTG G } \\
\text { CYY YYY GCR RAG TCG STG CCC T }\end{array}$ & 1150 & 60 & Group 4 & Desulfobacter sp \\
\hline DCC1165 & $\begin{array}{l}\text { GAT CAG CCA CAC TGG RAC TGA CA } \\
\text { GGG GCA GTA TCT TYA GAG TYC }\end{array}$ & 860 & 65 & Group 5 & $\begin{array}{l}\text { Desulfovibrio } \mathrm{sp} \\
\text { Desulfosarcina } \mathrm{sp} \\
\text { Desulfococcus } \mathrm{sp} \\
\text { Desulfonema } \mathrm{sp}\end{array}$ \\
\hline $\begin{array}{l}\text { DSV230 } \\
\text { DSV838 }\end{array}$ & $\begin{array}{l}\text { GRG YCY GCG TYY CAT TAG C } \\
\text { SYC CGR CAY CTA GYR TYC ATC }\end{array}$ & 610 & 61 & Group 6 & Desulfovibrio $\mathrm{sp}$ \\
\hline
\end{tabular}

*Ambiguities: R (G or A); Y (C or T); K (G or T); M (A or C); S (G or C); W (A or T).

$\dagger$ Primer DSB127 was derived from probe DSB129 described by Devereux et al. [10] apud Daly, Sharp and McCarthy [8].

\section{DNA Sequencing}

Fragments generated by the primers described above and in Table 2 were sequenced to confirm the identity. PCR reactions were performed in 10 $\mu \mathrm{L}$ volumes of a reaction mixture containing sterile distilled water, $0.5 \mu \mathrm{L}$ of PCR buffer $(10 \mathrm{x}$, Applied Biosystems), $0.5 \mu \mathrm{L}$ of primer (50 pmol), $0.5 \mu \mathrm{L}$ of Big Dye (Applied Biosystems) and 1.0 $\mu \mathrm{L}$ of PCR products. Initially $96^{\circ} \mathrm{C}$ for $5 \mathrm{~min}$ (denaturation) and Thirty-five cycles were performed: $96^{\circ} \mathrm{C}$ for $10 \mathrm{~s}$ (denaturation), $50^{\circ} \mathrm{C}$ for $5 \mathrm{~s}$ (annealing), $60^{\circ} \mathrm{C}$ for 4 min (extension) and 60 $\mathrm{s}$ of initial and terminal delay. Sequencing was performed on ABI 3130 automatic sequencer (Perkin-Elmer, Massachusetts, USA).

\section{Sequence assembly and alignment}

Sequences were edited using Staden Package (Staden et al. 2000) and aligned on the basis of similarity by the means of the sequence editor ClustalW (Thompson et al. 1994). Sequence analysis was performed using the sequence alignment software BLASTn run against the NCBI database (NCBI 2009), and the determined sequences were aligned using ClustalW. Distance analysis was conducted using MEGA (Molecular Evolutionary Genetics Analysis) version 5
(Tamura et al. 2005), with bootstrap support being obtained from 1000 pseudo replicates. Trees were viewed in Treeview (Daly et al. 2000). Parsimony analysis was conducted using Paup (Marshall et al. 1971), with branch support being obtained after 1000 heuristic search pseudo-replicates, as well as random stepwise taxon addition and tree-bisection reconnection as the heuristic search method.

\section{RESULTS AND DISCUSSION}

Table 1 is presented a list of 49 metallic coupons (MCs), which were collected during two periods (exposure to the Itajai-Açú River water during 30 and 90 days). The groups of bacteria detected on the metallic coupons surface are shown in Figure 3. The specification of different alloys in Table 1 is according of their chemical compositions, which are classified using a standardized code. For example, the carbon steel is essentially formed by iron and carbon with percentage of carbon among 0.008 at $2.11 \%$. The stainless steel is an ironchromium alloy, which can contain nickel, molybdenum and other elements that has superior physical properties to that of common steel and high resistance to oxidation is the main feature. 
It was possible to detect SRB on metals ASTM A53, ASTM A36 and SAR 50BN (Table 1, Fig. 2 and Fig. 3) that showed uniform corrosion (Fig. 2, indicated by arrows) with 90 days of exposure. The other metals coupons did not show tuber of corrosion (Fig. 2), showing the absence of SRB using the selective medium (Fig. 3).

All the metallic coupons of each metal collected, regardless of the presence, or absence of tuber of corrosion, were shaved on one side using new sterile surgical blades and all the material deposited on the surface were collected, then total DNA was extracted from these samples. The amplification of target sequences from the SRB with specific primers was performed by electrophoresis on agarose gels. After resolving the PCR products, some of the samples from the alloy were selected and the product was sequenced to check the presence of the SRB.

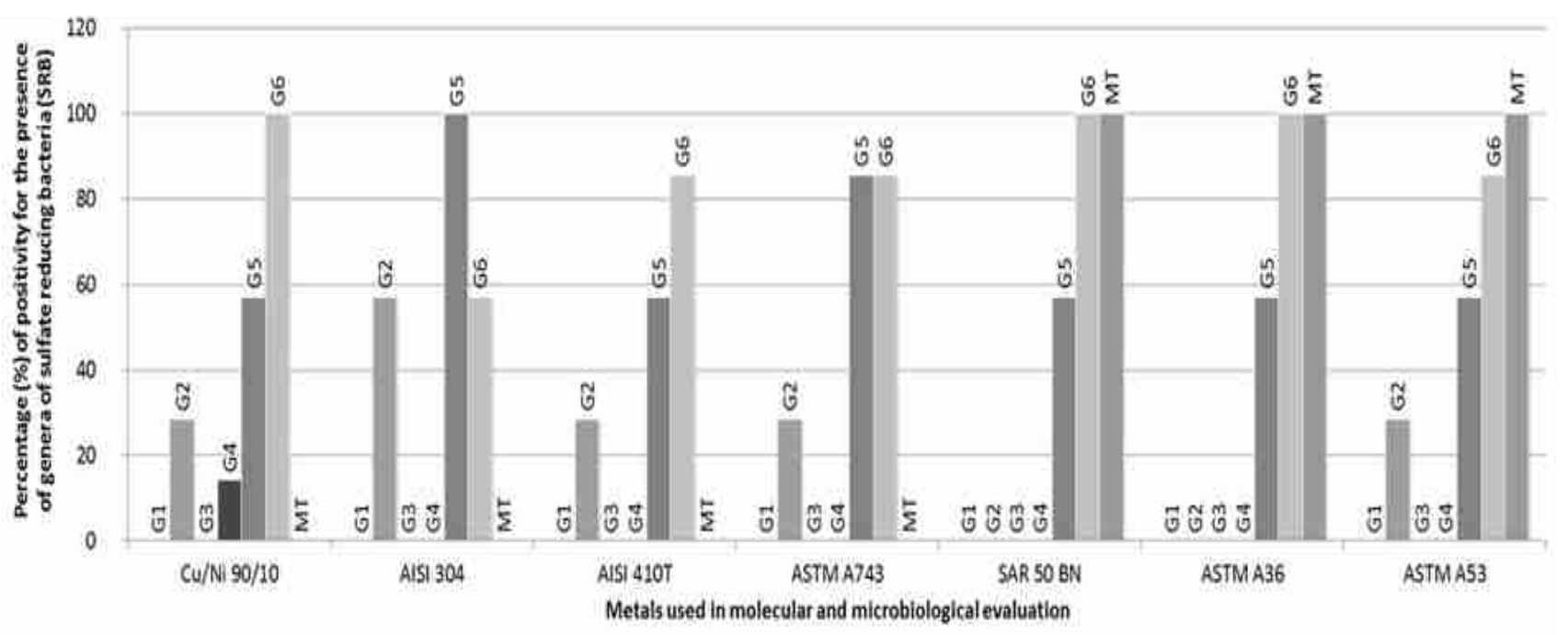

Figure 3 - Graphical representation of results obtained with the metallic coupons collected in two periods of exposure showing which BRS groups were identified in each metal and the percentage of positive results. Note: All legends (G1-G6) are listed on table 2, G1 (Group 1), G2 (Group 2), G3 (Group 3), G4 (Group 4), G6 (Group 5) and MT (Microbiological tests - selective medium ML).

The Group 1 of SRB, which included the genus Desulfotomaculum sp, and the Group 3, composed of Desulfobacterium sp was not found in any of the metals collected during the first and second collection phase $(30-90$ days exposure, respectively). However, the Group 2 of SRB, represented by Desulfobulbus sp, was found on all the metals, except SAR 50BN and ASTM A36 (Table 1). The Goup 4 of SRB, which comprised Desulfobacter $\mathrm{sp}$, were observed only in $\mathrm{Cu} / \mathrm{Ni}$ 90/10 from both the collection phases (30 and 90 days) (Fig. 3). The SRB from Group 5, which included the genera Desulfovibrio sp., Desulfosarcina sp., Desulfococcus sp. and Desulfonema, and also from Group 6, composed exclusively by Desulfovibrio sp were observed on all the metal alloys tested from the first and second collection.

This methodology that involves the amplification with specific primers for SRB genera allows not only the detection of these bacteria with metal corrosion tubercles already developed, but also those where there is still formation of corrosion tubercles with the presence of oxides and other materials, a result of the MIC. Thus, despite the presence or absence through the use of selective medium being effective in the case of corrosion after prolonged period, the initial stages of the process, which comprised the colonization of the metal, especially SRB, could only be observed through the amplification of total DNA with specific primers for the groups mentioned (Table 2).

The metals ASTM A53, ASTM A36 and SAR 50 $\mathrm{BN}$ were the only metals showing a positive result (100\% of samples) for the presence of SRB by using the selective medium (Fig. 3). The PCR analysis showed positive results for all the metals tested for Desulfovibrio sp (Group 6 - Table 2), ranging between 86 and 100\% (Fig. 3 and Table 
2), except the sample AISI 304 stainless steel, which showed $57 \%$ positive for the genus, but $100 \%$ in Group 5 (Table 2), which comprised, among others, also Desulfovibrio sp.

Hydroelectric power stations suffer many problems due to biocorrosion and biofouling on metallic surfaces and pipes, such as obstruction of cooling systems and stoppage of power generation units. These problems can lead to severe economic losses and interrupt the energy supply, resulting in penalties applied by the regulatory agency (ANEEL, 2012). Biocorrosion affects other industrial sectors as well, such as pipes carrying drinking water (Teng et al. 2008), the dairy industry (Simões et al. 2010), or any system that involves materials exposed to natural and artificial water, such as carbon steel (Duan et al. 2008) and stainless steel (Sheng et al. 2007).

Generally, biofilms require long periods before the adhesion of bacteria, such as SRB, on metal surfaces actually happens. Models that anticipate the biofilm production, such as the one presented by Marshall et al. (1971) and Surman et al. (1996) show that there is an enormous chain of reactions and events occurring on the metallic surfaces that contribute to the formation of biofilms where the SRBs get attached and develop. There are many types of mechanisms for the establishment and maturation of the biofilm and it may occur via different metabolic pathways, such as those explained by Coetser and Cloete (2005) and Simões et al. (2010). Although there is considerable diversity of microorganisms in the biofilms, the SRB are known to be responsible for increased corrosion, especially in carbon steel (Pérez et al. 2007; Castaneda and Benetton 2008).

SRB may act as an indicator for potential risk reduction by biocorrosion in the hydroelectric power stations. It now appears possible that a simple and effective tool for monitoring submerged metals and alloys could help prevent damage caused by the MIC. In this work, the samples were obtained directly from the mature biofilms, and it was possible to purify the total genomic DNA directly from the biofilm and then amplify them with specific primers for the detection of SRB. This methodology could even reduce the time consumed for the detection of SRB in those environments. In previous work, Daly et al. (2000) employed a similar methodology; however, they required additional steps to confirm the positive samples, which were not necessary for the present work. The confirmation of the correct bacteria genera was conducted by the sequence analysis previously described.

Although microbiological tests can be considered as functional methodology, the molecular approach allows greater accuracy in the analysis, eliminating possible methodological limitations due to the organism physiology, mostly because SRB show exigent metabolism and extreme conditions for culture, which make difficult their isolation among all the others bacteria existing in the biofilm. Still, through the specific primers for the SRB groups, the time consumed between the collection of the sample and positive identification was considerably reduced (approximately 5 to 7 days), compared to the time spent with the microbiological tests, which could take up to 50 days until the results were available.

The employment of specific primers for the SRB groups confirmed the presence of SRB in metal alloys considered positive in the test of presence or absence of SRB by the microbiological tests (Fig. $3)$. In addition, SRB were detected even in the metals that showed negative results by the microbiological tests, such as the sample of metals alloys ASTM A743, AISI 410T, INOX AISI 304 and $\mathrm{Cu} / \mathrm{Ni} 90 / 10$ that showed negative results in culture with ML medium (Fig. 3). With early monitoring, corrective actions could be employed to reduce the losses that overtax the companies involved in the hydroelectric construction and improve hydroelectric power station management. By improving the causes of corrosion, as well as the types of corrosion that attack on metallic surfaces, significant financial losses could be avoided.

\section{CONCLUSIONS}

The results showed the presence of SRB on the metallic coupons by the conventional microbiological techniques, which, however, was time consuming and often did not reflect the true diversity present on these metals. The isolation of these bacteria was possible only for MC already showing the signs of corrosion, which might have led to false negative results. On the other hand, the DNA assessment for the targeted microorganisms by the specific primers allowed early detection of SRB, even on the metal that had not undergone the process of corrosion. It was also possible to decrease the time between the collection and 
identification of the target microorganisms, as the steps for the isolation and growth of bacteria were eliminated.

This study provided methodological support for the concessionaire responsible for building the hydroelectric power station, aiding in the search for alternatives to prevent possible problems associated with the presence of microorganisms responsible for biocorrosion. Although corrosion is a natural process, the presence of SRB accelerates the corrosion rate; therefore, alternatives to prevent and detect the potential problems could be employed in attempt to reduce the economic losses. Finally, this methodology was sensitive enough to detect SRB, which were associated with the corrosion, even before visual observation of corrosion tubers on the metals was noted.

\section{REFERENCES}

ANEEL, Agência Nacional de Energia Elétrica. Relatório de Informações Gerenciais. Banco de informações de geração ANEEL (BIG) 2012, march.

Beech IB, Gaylarde CC. Recent advances in the study of biocorrosion - an overview. Rev Microbiol. 1999; 30: 177-190.

Beech IB, Sunner J. Biocorrosion: towards understanding interactions between biofilms and metals. Curr Opin Biotechnol. 2004; 15: 181-186.

Ben-Dov E, Brenner A, Kushmaro A. Quantification of Sulfate-reducing Bacteria in Industrial Wastewater, by Real-time Polymerase Chain Reaction (PCR) Using dsrA and apsA Genes. Microb Ecol. 2007; 54: 439-451.

Boden R, Cleland D, Green PN, Katayama Y, Uchino Y, Murrel JC, Kelly DP. Phylogenetic assessment of culture collection strains of Tiobacillus thioparus, and definitive 16S rRNA gene sequences for $T$. thioparus, T. denitrificans, and Halothiobacillus neapolitanus. Arch Microbiol. 2012; 194(3): 187-195.

Castaneda H, Benetton XD. SRB-biofilm influence in active corrosion sites formed at the steel-electrolyte interface when exposed to artificial seawater conditions. Corros Sci. 2008; 50:1169-1183.

Clescerl LS, Greenberg AE, Eaton AD. Standard Methods for the Examination of Water and Wastewater. 20th ed. Washington: American Public Health Association; 1999.

Coetser SE, Cloete TE. Biofouling and biocorrosion in industrial water systems. Crit Rev Microbiol. 2005; 31: 213-232.
Daly K, Sharp RJ, McCarthy AJ. Development of oligonucleotide probes and PCR primers for detecting phylogenetic subgroups of sulfate-reducing bacteria. Microbiology. 2000; 146: 1693-1705.

Devereux R, Delaney M, Widdel F, Stahl DA. Natural relationships among sulfate-reducing eubacteria. $J$ Bacteriol. 1989; 171: 6689-6695.

Devereux R, Hines ME, Stahl DA. S cycling: characterization of natural communities of sulfatereducing bacteria by $16 \mathrm{~s}$ rRNA sequence comparisons. Microb Ecol. 1996; 32: 283-292.

Devereux R, Kane MD, Winfrey J, Stahl DA. Genusand group-specific hybridization probes for determinative and environmental studies of sulfatereducing bacteria. Syst Appl Microbiol. 1992; 15: 601-609.

Duan J, Wu S, Zhang X, Huang G, Du M, Hou B. Corrosion of carbon steel influenced by anaerobic biofilm in natural seawater. Electrochim Acta. 2008; 54: 22-28.

Eguía E, Trueba A, Girón A, Río-Calonge B, Otero F, Bielva C. Optimization of biocide dose as a function of residual biocide in a heat exchanger pilot plant effluent. Biofouling, 2007; 23: 231-247.

Heitz E, Fleming HC, Sand W. Microbially influenced corrosion of materials. Berlin Heidelberg: Springer Verlag; 1996.

Kumar MA, Anandapandian KTK, Parthiban K. Production and Characterization of Exopolysaccharides (EPS) from biofilm Forming Marine Bacterium. Braz Arch Biol Tech. 2011; 54: 259-265.

Marschall C, Frenzel P, Cypionka H. Influence of oxygen on sulfate reduction and growth of sulfatereducing bacteria. Arch Microbiol. 1993; 159: 168173

Marshall KC, Power KN, Angles ML, Schneider RP, Goodman AE. Analysis of bacterial behavior during biofouling of surfaces. In: Geesey GG, Lewandowski $\mathrm{Z}$, Flemming HC. Biofouling and Biocorrosion in Industrial Water Systems. Florida, USA: CRC Press; 1994. 137-150.

Marshall KC, Stout R, Mitchell R. Mechanism of initial events in the adsorption of marine bacteria to surfaces. J Gen Microbiol. 1971; 86: 337-348.

NCBI [Internet]. National Center for Biotechnology Information website. c2006 [cited 2009 Sep 21]. Available from: http://www.ncbi.nlm.nih.gov/.

Pérez EJ, Cabrera-Sierra R, González I, Vives FR. Influence of Desulfovibrio sp. biofilm on SAE 1018 carbon steel corrosion in synthetic marine medium. Corros Sci. 2007; 49: 3580-3597.

Romeo T. Bacterial Biofilm. Curr Top Microbiol. Berlin: Springer-Verlag; 2008. 
Schaechter M. The Desk Encyclopedia of Microbiology. London, UK: Elsevier Academic Press; 2004.

Sheng X, Ting Y, Pehkonen SO. The influence of sulphate-reducing bacteria biofilm on the corrosion stainless steel AISI 316. Corros Sci. 2007; 49: 21592176.

Simões M, Simões LC, Vieira MJ. A review of current and emergent biofilm control strategies. LWT - Food Sci Technol. 2010; 43: 573-583.

Staden R, Beal KF, Bonfield JK. The Staden package. Methods Mol Biol. 2000; 132: 115-130.

Surman S, Morton G, Keevil B. Biofilms: an overview. PHLS Microbiology Digest. 1996; 13: 33-38.

Tamura K, Peterson D, Peterson N, Stecher G, Nei M, Kumar S. MEGA5: Molecular Evolutionary Genetics Analysis using Maximum Likelihood, Evolutionary Distance, and Maximum Parsimony Methods. Mol Biol Evol. 2011; 28: 2731-2739.
Teng F, Guan YT, Zhu WP. Effect of Biofilm on cast iron pipe corrosion in drinking water distribution system: Corrosion scales characterization and microbial community structure investigation. Corros Sci. 2008; 50: 2816-2823.

Thompson JD, Higgins DG, Gibson TJ. CLUSTAL W: improving the sensitivity of progressive multiple sequence alignment through sequence weighting position specific gap penalties and weight matrix choice. Nucleic Acids Res. 1994; 22: 4673-4680.

Videla HA.Biocorrosão, Biofouling e Biodeterioração de Materiais. 1st ed. São Paulo: Blucher; 2003.

Zadvorny OA, Zorin NA, Gogotov IN. Transformation of metals and metal ions by hydrogenases from photrophic bacteria. Arch Microbiol. 2006; 184: 279285.

Received: March 15, 2012; Accepted: June 26, 2013. 